\title{
DOES ELEMENTARY SCHOOL TEACHER PERFORMANCE MATTER?
}

\author{
Muhamad Afandi ${ }^{1 *}$, Sri Wahyuningsih ${ }^{2}$, Linda Ika Mayasari ${ }^{3}$ \\ ${ }^{1}$ Universitas Islam Sultan Agung-Semarang, Indonesia \\ ${ }^{2}$ Institut Agama Islam Negeri Kudus, Indonesia \\ ${ }^{3}$ Sekolah Tinggi Keguruan dan Ilmu Pendidikan Kusumanegara, Indonesia \\ *e-mail: mafandi@unissula.ac.id
}

\begin{abstract}
The performance of teachers in realizing holistic education can be observed from how the teachers prepare, implement, and evaluate the learning process or their pedagogic knowledge. This study aims to examine the teachers' ability to plan, implement and evaluate to assess their performance in the elementary school learning process based on tenure and gender. This research is a quantitative study with direct observation, which was conducted on 162 elementary school teachers from 30 public elementary schools in Semarang, Indonesia. Data were collected using assessment sheets. The observer was the principal which belonged to the same school as the respondent. The data were then validated using Pearson's correlation based on group tenure and gender. The instrument was analyzed using structural equation modelling (SEM) and showed that the imposition of the confirmatory factor analysis (CFA) was achieved more than a critical value of .50 which meant that the construct was valid and reliable. The understanding on teachers' performance was indicated by teachers' activities in preparing their class. This study found that there was no significant correlation between teachers' performance and teaching experience or that and gender.
\end{abstract}

\section{Keywords: teachers' performance, planning, implementation, assessment, elementary school.}

\section{APAKAH KINERJA GURU DI SEKOLAH DASAR BERMASALAH?}

\begin{abstract}
Abstrak. Kinerja guru dalam mewujudkan pendidikan yang holistik dapat diamati dari bagaimana guru menyiapkan, menerapkan, dan mengevaluasi proses pembelajaran atau pengetahuan pedagogi guru. Penelitian ini bertujuan untuk menguji kamampuan merencanakan, melaksanakan, dan penilaian sebagai kinerja guru dalam proses pembelajaran sekolah dasar yang didasarkan pada masa kerja dan jenis kelamin. Penelitian ini merupakan penelitian kuantitatif dengan observasi langsung yang dilakukan kepada Guru sekolah Dasar yang berjumlah 162 guru dari 30 Sekolah Dasar Negeri di Kota Semarang, Indonesia. Data dikumpulkan dengan menggunakan lembar penilaian. Pengamat adalah kepala sekolah dari sekolah yang sama dari masing-masing responden. Data kemudian divalidasi menggunakan korelasi Pearson berdasarkan masa kerja kelompok dan jenis kelamin. Analisis instrumen menggunakan Structural Equation Modelling (SEM) yang menunjukkan bahwa penerapan analisis faktor konfirmatori (CFA) lebih dari nilai kritis 0,50 yang berarti konstruk tersebut valid dan reliabel. Pemahaman tentang kinerja guru ditunjukkan dengan aktivitas guru dalam mempersiapkan kelasnya. Penelitian ini menemukan bahwa tidak ada korelasi yang signifikan antara kinerja guru dengan pengalaman mengajar dan jenis kelamin.
\end{abstract}

Kata Kunci: kinerja guru, perencanaan, pelaksanaan, penilaian, sekolah dasar.

\section{INTRODUCTION}

Education aims to develop the potential, knowledge, insights and experiences of students. It is a process that involves cognitive, affective and psychomotor aspects (Markle \& Banion, 2014). A holistic learning process must be able to be developed when the aspects possessed by the student. Teachers as an educator have main task on educating, teaching, guiding, directing, training, and evaluating students. They play a main role in the implementing the curriculum (Sumual \& Ali, 2017). Moreover, they are expected to have the teachers' competences. One of them is pedagogical competence which can help them face the diversity of students especially in elementary schools (Mumpuniarti, Handoyo, Pinrupitanza, \& Barotuttaqiyah, 2020). In recent years, the teachers' quality and effectiveness 
have been the major issue in educational settings (Dutta, Halder, \& Sen, 2017; Mahgoub \& Alyas, 2014; Siri, Supartha, Sukaatmadja, \& Rahyuda, 2020). Further, the teacher performance and teacher effectiveness are utilized as the basis for decisions about continued employment, tenure and promotion, and financial aspect (Morgan, Hodge, Trepinski, \& Anderson, 2014).

Meanwhile, the performance of teachers in realizing holistic education can be observed from how the teacher prepares the implementation and evaluation on the learning process or teacher's pedagogic knowledge (Murkatik, Harapan, \& Wardiah, 2018). Pedagogic knowledge helps them to compile learners based on scientific facts to develop more meaningful learning process (Keengwe \& Onchwari, 2011). In other words, teacher performance is a determiner of learning process which reflects the teacher's pedagogic knowledge (Hakim, 2015). Teacher's ability in learning aspects is an important factor that determines performance shown by level of expertise on conducting learning process (Usop, Askandar, Langguyuan-Kadtong, \& Usop, 2013). They have played a vital role in educating the students. Regarding it, elementary teachers in Indonesia are supposed to have better performances in teaching. This can be reviewed through their teaching activities at schools. It covers the ways of how they prepare teaching activities; implement their teaching activities and conducting assessments for their students.

Several studies related to teacher performance and curriculum examined how improving teachers' performance can be conducted using training and development in Ghana (Hervie \& Winful, 2018). Obara \& Sloan (2010) explored the performance standards implementation in mathematics learning still effective for teachers to conduct a learning process following the new curriculum. Also, Alghamdi \& Al-Salouli (2013) investigated the effect of science teachers' perceptions of their performance and learning process, mainly when the new curriculum focuses on critical thinking and problem-solving is applied. Then various approaches can be developed to assess and evaluate teacher performance. Hassan, Alias, Saleh, \& Awang (2017), involving engineering teachers, investigated the teacher performance which can be assessed from students' perception. Further, Lee, Lam, \& Li (2003) described how far the learning process' effectiveness and evaluation on the teacher's performance. Meanwhile, Ohle. Boone, \& Fischer (2015) explored the relationship of content knowledge (CK) possessed by physics teachers to the students' interest and achievement. In a broader area, Blömeke \& Delaney (2012) highlighted the mathematics teachers' knowledge across countries briefly.

Unlike the previous studies exploring teachers' performance viewed from the students' perception and measuring the teacher's performance in certain subjects such as physics and mathematics, this present study more focuses on assessing teachers' performance in one of Indonesian elementary schools during the teaching and learning process on all subjects including Mathematics, Physics, Religion, Language, Civic Education and so on. Moreover, it investigates the ways of how they plan, implement, and give the assessment on their teaching activities in the classroom since it is important to understand deeply, how much teacher performance related to the teaching activities to develop comprehensive approach in teaching assessment.

The main reason for emphasizing the elementary school teachers in Indonesia is to get more data regarding the real understanding of teachers and school activities in Indonesian elementary school particularly in Banyumanik District, Central Java, Indonesia. This study aims to test the ability to plan, implement and evaluate teacher performance in the primary school learning process based on tenure and gender.

\section{METHODS}

This study used quantitative method with direct observation to measure the performance of elementary school teachers in teaching activities in the city of Semarang. This study employed teaching activities as a latent variable or main construct, which consisted of indicators as subconstructs, such as preparation, implementation and evaluation. The sampling technique was carried out using stratified random sampling with the determination of respondents using a lottery. A total of 162 elementary school teachers from 30 public schools in Banyumanik District, Semarang City were used as research respondents. 
The respondents were drawn based on Teacher Working Group/ Cluster then samples were taken randomly to obtain representative portion. Teacher performance data were observed using assessment sheets instruments equipped with assessment scale. The observers in this study was the principals from same school as the respondent work Homebase. Before the instrument used to collect the data, the observers were trained on how to use the assessment sheets instrument, data collection techniques, to avoid personal perspectives or observer's bias.

The instrument consists of three indicators, eight sub-indicators and total of 64 statement (Table 1). The instrument was also completed with assessment rubric to explain scoring scale form 1-4. It helps all observers to gain same perspective and understanding in learning observation. Before used, the instrument was validated by three elementary school learning experts. Expert validation included language (legibility, easy to understand, and unambiguous), and statement compatibility to conduct evaluation (reliability, relatability, and on target). The validation aimed to determine the shortcomings of instruments.

\section{Instrument Calibration}

The instrument was calibrated for twice, using expert validation and statistic calculation. For the first, after the validated instrument was determined by the experts, then the instrument was used for observing teacher performance as a data collection in the primary school where each respondent was located. The second part, after data collection, the instrument was validated by analyzing the constructed structure among indicators, sub-indicators, and loading factors. The analysis was done through calculation of confirmatory factor analysis (CFA). The questionnaires stated as valid instrument if it fulfils the criteria as mention in Table 2 .

Table 1. Number of Statements per Indicator to Observe Teacher's Performance

\begin{tabular}{llc}
\hline Indicators & Sub-Indicators & $\begin{array}{c}\text { Number of } \\
\text { Statements }\end{array}$ \\
\hline Planning & Learning instrument preparation: Identification of the learning plan's components & 11 \\
Learning activities & Introduction activities & 5 \\
& 1. Conducting apperception and motivation activity & 2 \\
2. Delivering learning competencies and activity plans & 4 \\
Main learning activities & 7 \\
1. Mastering subject material during learning process & 5 \\
2. Applicating various learning strategies in learning process & 4 \\
3. Applicating scientific learning approach (scientific process-based approach) & 4 \\
4. Applicating integrated thematic learning/ intra thematic learning & 5 \\
5. Utilizing learning resources/ media in learning & 2 \\
6. Involving students in discussion during learning process & 4 \\
7. Use of correct and appropriate language in learning & 5 \\
Conclusion & 1. Conducting reflection, assessment and evaluation & 2 \\
Teacher's cognitive evaluation & 4 \\
Learning product evaluation & 64
\end{tabular}

Note: the number of statements are used for loading factor in path analysis

Table 2. Benchmark Value for Validity and Reliability Parameter

\begin{tabular}{ll}
\hline Parameter & Benchmark Value \\
\hline Validity & $\geq .50$ \\
Standardized loading & $\leq .50$ \\
Error variant & $\mathrm{n} / \mathrm{d}$ \\
Reliability & $\geq .70$ \\
Convergent validity (CV) & $\geq .50$ \\
Variance extracted (VE) & $\mathrm{n} / \mathrm{d}$ \\
Construct reliability (CR) & \\
Discriminant validity (DV) &
\end{tabular}

Note $: \mathrm{n} / \mathrm{d}=$ not determined because the parameter is not considered in this research 


\section{Data Analysis Technique}

Structural equation modelling (SEM) analysis was carried out using software packages Lisrel version 8.80 (Vieira, 2011). The estimation method of the relationship between variables and indicators using Maximum Likelihood (ML) with input for each analysis was covariance matrix of items or scale scores (Voelkle, Oud, von Oertzen, \& Lindenberger, 2012). The dependent variable was teacher performance or expressed as main construct, which was analyzed through a causative relationship with three indicators and seven sub-indicators (Table 3). Teacher performance variable was measured through observation on each indicator in the form of planning, implementation and evaluation of learning. The learning implementation planning indicator $(\eta 1: X 1)$ consisted of identity and components of the learning implementation plan (RPP) as one and only sub-indicator.
The results of observations were tabulated and coded, before proceeding to model tested using univariate and multivariate normality. The assumption of normality was expressed in statistical value of $z$ (normal data) for skewness (the tendency of data distribution to lean left or right) and kurtosis (the peak condition of the graph is neither convex nor transparent). If the $z$ value $\left(Z_{\text {kurtosis }}\right.$ and or $\left.Z_{\text {skewness }}\right)$ was greater than $.05(\alpha=5 \%)$ then it can be said that the data distribution was normal. Calculation and construction of SEM models on data that were not normally distributed can still be done using the ML-method. Structuring of SE M was constructed by correcting standard errors and some goodness of fit indices (GFI) utilization (Awang, Afthanorhan, \& Asri, 2015; Hosseinifard \& Abbasi, 2012; Smits, Timmerman, \& Stegeman, 2016).

\section{Table 3. Structural Component Definition to Construct SEM Path Analysis}

\begin{tabular}{lll}
\hline Variable & Indicator & Sub Indicator \\
\hline Teacher performance $\left(\xi_{1}\right)$ & Planning $\left(\eta_{1} ; \mathrm{X} 1\right)$ & Learning instrument preparation $\left(Y_{1}\right)$ \\
& Learning activities $(\eta 1 ; \mathrm{X} 2)$ & Introduction activities $\left(Y_{2}\right)$ \\
& & Main learning activities $\left(Y_{3}\right)$ \\
& Evaluation $(\eta 1 ; \mathrm{X} 3)$ & Conclusion $\left(Y_{4}\right)$ \\
& Cognitive evaluation $\left(Y_{5}\right)$ \\
& Learning product evaluation $\left(Y_{6}\right)$ \\
& Learning situation evaluation $\left(Y_{7}\right)$ \\
\hline
\end{tabular}

The validity hypothesis of the SEM structural model was tested through the Goodness-of-Fit Index (GFI) which consisted of 18 parameters (Table 4 ). In addition, external factors are measured to determine whether there was influenced or relevance to teacher performance. The factors measured include gender (male versus female) and the service period of service as a professional teacher.

\section{Model Specifications}

This study used an analysis of the structural second order model of confirmatory factor analysis (CFA $2^{\text {nd }}$ order) to see the causality relationship between the sub-indicators and indicators of teacher performance assessment. Model specifications were constructed by converting path charts into a series of measurement model equations.

\section{Correlation Analysis between Working Period (Experience), Gender and Teacher Performance}

The Pearson analysis was conducted using SPSS ver. 23 to understand correlation between working period (experience), gender and teacher performance. The significant correlation was determined if the significance value $\leq \alpha$-value $=$ .05 .

\section{FINDINGS AND DISCUSSION Findings}

Based on the univariate normality test, there were only two sub-indicators that were distributed normally, i.e. learning conclusions (Y4) and cognitive evaluation (Y5). This was indicated by $p$-value of skewness and kurtosis that were higher than .05 (Table 4). This indicates that data distribution of Y4 and Y5 have data meant equal to data mode. 
Table 4. Univariate and Multivariate Analysis of Sub-Indicator Data Distribution

\begin{tabular}{|c|c|c|c|c|c|c|c|c|}
\hline \multirow{2}{*}{ Variable } & \multicolumn{3}{|c|}{ Skewness } & \multicolumn{3}{|c|}{ Kurtosis } & \multicolumn{2}{|c|}{ Skewness and Kurtosis } \\
\hline & Value & $z$-score & $p$-value & value & e $z$-score & $p$-value & chi-square & $p$-value \\
\hline \multicolumn{9}{|l|}{ Univariate normality } \\
\hline Instruments preparation (Y1) & & -4.25 & .000 & & 1.76 & .078 & 21.203 & .000 \\
\hline Introduction activities (Y2) & & -2.35 & .019 & & 1.38 & .169 & 7.436 & .024 \\
\hline Main activities (Y3) & & -2.36 & .018 & & 1.13 & .260 & 6.839 & .033 \\
\hline Conclusion (Y4) & & .22 & .825 & & .13 & .898 & .065 & $.968^{*}$ \\
\hline Cognitive evaluation (Y5) & & .48 & .632 & & -1.14 & .254 & 1.532 & $.465^{*}$ \\
\hline Output evaluation (Y6) & & -3.04 & .002 & & 1.18 & .237 & 10.613 & .005 \\
\hline Situation evaluation (Y7) & & .82 & .412 & & -2.30 & .003 & 9.659 & .008 \\
\hline \multicolumn{9}{|l|}{ Multivariate normality } \\
\hline & 8.717 & 7.383 & .000 & 66.69 & 92.198 & .028 & 59.345 & .000 \\
\hline
\end{tabular}

Note: Star mark $\left(^{*}\right)$ shows the normality of data distribution (mean equal to modus and median)

Although the data was normally distributed for testing two sub-indicators univariately, multivariate testing for all subindicators showed the opposite results. The multivariate normality test was conducted and the result showed that $p$-value of skewnesss and Kurtosis were $<.05$. SEM modelling analysis was still used in this research for assessing the constructs of theoretical model of relationship among sub-indicators, indicators and variables.

\section{CFA $2^{\text {sd }}$ Order}

The SEM construction results shown that the seven sub indicators were valid and reliable in forming teacher performance variables, this result is presented in Table 5. This was indicated by the construct reliability (CR) value which shown the internal consistency of indicator was $\geq .70$. While based on the value of extracted variant, the data were considered reliable because the VE score was $\geq .50$, which means that variances quantity of indicators that was extracted by formed variables was more than the error variants.

In the validity and reliability analysis of CFA, sub-construct or planning, teaching activities, and evaluation indicators have a value of $C R \geq .70$ and $V E$ values $\geq .50$. So, it can be concluded that the three indicators were reliable in develop teacher performance as the main variable. SEM analysis was visualized to describe the relationship between main variable to the indicator, as well as the indicators to the sub-indicators (Figure 1).

Table 5. Validity and Reliability Analysis of Variable

\begin{tabular}{|c|c|c|c|c|c|c|c|}
\hline \multicolumn{2}{|c|}{ Latent Variable } & \multirow{2}{*}{ Manifest Variable } & \multirow{2}{*}{$\begin{array}{l}\text { Standardized } \\
\text { Loading }\end{array}$} & \multirow{2}{*}{$\begin{array}{c}\text { Error } \\
\text { Variant }\end{array}$} & \multicolumn{2}{|c|}{ Reliability } & \\
\hline Construct & Sub-Construct & & & & $\overline{C R}$ & VE & \\
\hline \multirow{7}{*}{$\begin{array}{l}\text { CFA } 1^{\text {st }} \text { order } \\
\text { Teacher } \\
\text { performance } \\
\text { (TP) }\end{array}$} & Planning (X1) & $\begin{array}{l}\text { Learning instruments } \\
\text { preparation (Y1) }\end{array}$ & 1.00 & .01 & .99 & .99 & \multirow[t]{7}{*}{$\begin{array}{l}\text { Valid and } \\
\text { reliable }\end{array}$} \\
\hline & \multirow{3}{*}{$\begin{array}{l}\text { Teaching } \\
\text { activities (X2) }\end{array}$} & Introduction activities (Y2) & .79 & .37 & & & \\
\hline & & Main learning activities (Y3) & .88 & .23 & \multirow[t]{2}{*}{.86} & \multirow[t]{2}{*}{.67} & \\
\hline & & Conclusion (Y4) & .78 & .39 & & & \\
\hline & \multirow[t]{3}{*}{ Evaluation (X3) } & Cognitive evaluation (Y5) & .88 & .23 & \multirow[t]{3}{*}{.74} & \multirow[t]{3}{*}{.50} & \\
\hline & & Learning product evaluation (Y6) & .67 & .55 & & & \\
\hline & & Learning situation evaluation $(\mathrm{Y} 7)$ & .53 & .72 & & & \\
\hline \multirow{4}{*}{$\begin{array}{l}\text { CFA } 2^{\text {nd }} \text { order } \\
\text { Teacher } \\
\text { performance } \\
\text { (TP) }\end{array}$} & & & & & \multirow{4}{*}{.90} & & \\
\hline & Planning (X1) & & .73 & .46 & & \multirow[t]{3}{*}{.73} & \multirow{3}{*}{$\begin{array}{l}\text { Valid and } \\
\text { reliable }\end{array}$} \\
\hline & $\begin{array}{l}\text { Teaching } \\
\text { activities (X2) }\end{array}$ & & .89 & .21 & & & \\
\hline & Evaluation (X3) & & .97 & .06 & & & \\
\hline
\end{tabular}




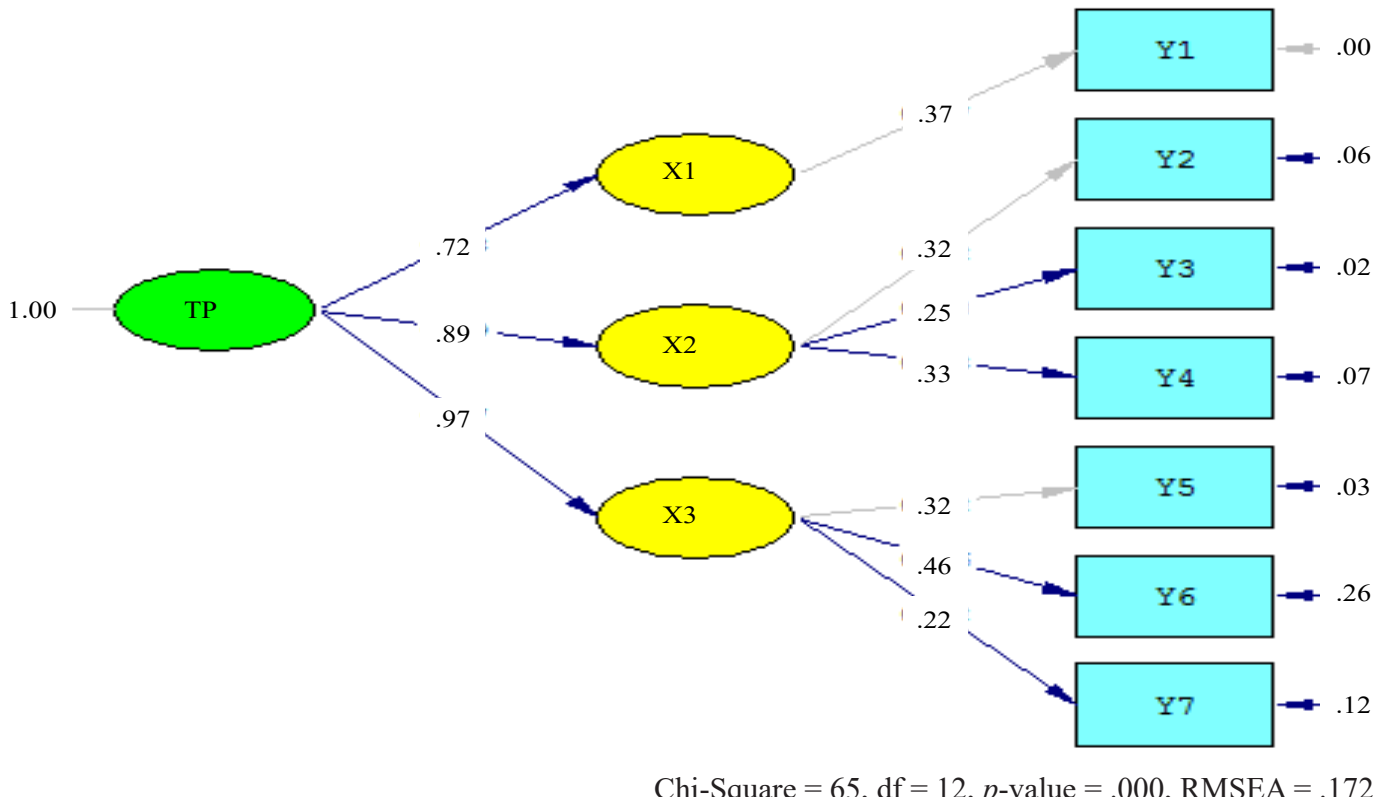

Figure 1. SEM Analysis Showing the Model of Learning Processes' Sub-Indictors to Teacher Performance

SEM modelling that was formed resulted the direction of causative effect between teacher performance and planning indicators, main teaching activities and evaluation. The calculation results showed that the CFA $2^{\text {nd }}$ order factor loading teacher performance was worth more than a critical value of .50. The value of the factor loading of variable teacher performance on planning indicators was .73 and with $R^{2}$ of .54 , the teaching activities indicator showed a factor loading value of .89 and $R^{2}$ of .79 , while in the evaluation indicator the factor loading value is .97 with $R^{2}$ of .94 . Based on this, the variables with indicators have a high causative effect.

Meanwhile, based on the CFA $1^{\text {st }}$ order calculation also showed the high linkages of causative effects between indicators and subindicators. The average loading factor at CFA
1 st order is in the range below .50 but has a standardized factor loading and the range $R^{2}$ is above .50 except for the evaluation indicator for learning product evaluation (Y6) and situation evaluation (Y7) which are successively each has $R^{2}$ value of .46 and .22 . Based on this explanation, the analysis model showed that both variable to indicators and indicators to sub-indicators have a causative effect.

Based on the combination analysis of statistical goodness of fit indices parameters, as many as 10 out of 18 parameters were stated that the causative model between teacher performance scores and indicators in this study was generally good fit (Table 6). It was indicated that the teacher's performance has a causative relationship with sub-indicators that compose the primary school teacher population.

Table 6. The Goodness of Fit Analysis

\begin{tabular}{llcl}
\hline Parameters & Benchmark for Acceptable Compatibility & Model Index & Status \\
\hline Chi-Square & Smaller than $F$ table is better & 63.430 & $\begin{array}{l}\text { Poorly fit } \\
\text { Poorly fit }\end{array}$ \\
-value & $p \geq .05$ & .000 & $\begin{array}{l}\text { Good fit } \\
\text { GFI }\end{array}$ \\
& GFI $\geq .90$ (good fit), & .890 & \\
SRMR & $.80 \leq$ GFI $<.90$ (marginal fit) & .012 & Good fit \\
RMSEA & RMR $\leq .05$ & .170 & Marginal fit \\
& $.05<$ RMSEA $\leq .08$ (good fit), & & \\
CFI & $.08<$ RMSEA $\leq 1$ (marginal fit) & .940 & Good fit \\
& CFI $\geq .90$ (good fit), & & \\
\hline
\end{tabular}

Note: GFI = goodness-of-fit index; SRMR = standardized root mean square residual; RMSEA = root mean square error of approximation; $\mathrm{CFI}=$ comparative fit index. 
However, the results of the correlation analysis based on the work period (Table 7) and gender (Figure 2) did not indicate differences or association with learning activities as an indicator of the performance achievement of elementary school teachers. Observation data did not show any correlation and influence between years of service and teacher performance indicators. But the working period of $0-8$ years has the highest performance in planning, learning and evaluation activities when compared to other groups. This value has decreased in line with the period of employment while the lowest teacher performance was indicated by teachers with working period 16-24 years. Teacher performance figures in the 24-32 year working period have increased.

The same result was also shown by the results of assessment of teacher performance that related to the gender. In all aspects of the indicators, there was no correlation and association with gender. Based on statistical analysis, female teachers have higher levels of performance in all aspects on learning indicator even it was no significant difference with male teachers (Figure 2).

Table 7. Teacher Performance's Indicator Score Regarding Time Duration (Year) in Semarang Elementary School (Means $\pm S D)$

\begin{tabular}{lccc}
\hline Time Duration (year/y) & Planning & Learning Activities & Evaluation \\
\hline $0<y \leq 8$ & $3.68 \pm .35$ & $3.38 \pm .30$ & $3.21 \pm .41$ \\
$8<y \leq 16$ & $3.60 \pm .39$ & $3.27 \pm .37$ & $3.17 \pm .42$ \\
$16<y \leq 24$ & $3.40 \pm .40$ & $3.03 \pm .26$ & $2.93 \pm .32$ \\
$24<y \leq 32$ & $3.59 \pm .34$ & $3.19 \pm .19$ & $3.19 \pm .34$ \\
$\geq 32$ & $3.61 \pm .34$ & $3.12 \pm .33$ & $3.06 \pm .29$ \\
\hline
\end{tabular}

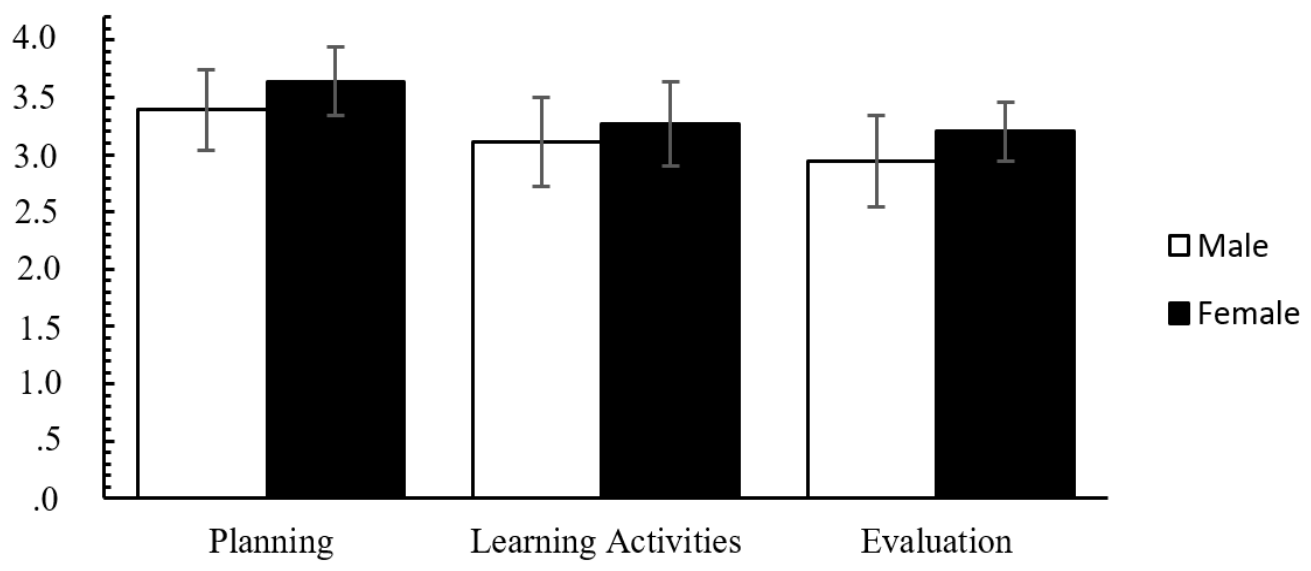

Figure 2. Teacher Performance Score Based on Gender in Semarang Elementary School

\section{Discussion}

Performance is a set of behaviours related to driving factors and the ability to achieve personal or an organizational goals. Teachers are professions and as educators have an important role in improving the quality of education (Early, Maxwell, Burchinal, Alva, Bender, Bryant, ... \& Zill, 2007). Based on this, teacher performance is one of the criteria for evaluating professionalism. Teacher performance can be assessed by referring to the activities and work of the teacher in facing the task as a teacher.
Teacher performance is an aspect that figuring capability in preparing learning plans, carrying out the learning process and implementing learning assessments in accordance with the objectives to be achieved (Bakar, 2018; Muin, Riyanto, \& Wibowo, 2020; Rinantanti, Bin-Tahir, \& Aminah, 2019). Departing from this, the teacher performance appraisal (PKG) of each rubric/activity item is divided into the first three indicators compiling learning plans (RPP Identity, Components, Indicators, Objectives, Learning Materials, Learning Methods, 
Learning Resources, Preliminary Activities, Activities core, Closing Activity, Assessment). The second indicator of the implementation of learning from the preliminary activities provides apperception and motivation, delivery of competencies and planned activities, at the core learning activities such as mastery of Learning Materials, Application of Educating Learning Strategies, Application of scientific learning approaches (scientific process-based approach), Application of Integrated Thematic Learning/Intra Thematic subjects, subject-based learning, utilization of learning resources/media in learning, involvement of students in learning, use of correct and appropriate language in learning, closing, and learning. Whereas in the third indicator, the teacher conducts assessments in learning including teacher assessment, assessment of mastery of knowledge, assessment of learning products, assessment of climate learning and assessment by students.

Syllabus is one form of learning planning that still requires a more operational translation into the form of a Learning Implementation Plan (RPP). RPP is a handle for teachers in carrying out learning both in class, laboratory, and/or field for each basic competency. Considering the planning of learning programs as one of the indicators of teacher performance, in this study the teacher's performance in question is in the form of the results of the teacher's activities in arranging learning programs in the form of syllabus and lesson plans.

Observation of performance appraisal conducted on primary school teachers in this study shows that the planning of learning in the form of syllabus and RPP that has been prepared has referred to the content standard. Syllabus and lesson plans have also been adapted to the learning approach used. Learning instruments that have been prepared by the majority teacher have included complete information such as the identity of the lesson plan, components, indicators, objectives, material and learning methods, and learning resources. Teacher performance of elementary teacher across Banyumanik district has high enough on preparation indicators. It showed that the teachers understand the learning process comprehensively and are able to prepare very well.

Referring to the 2013 curriculum, core learning activities must be competency-based, and characteristics carried out with an integrative thematic approach. The things that need to be considered in the learning process are the integration of learning materials with people's lives and identifying competencies and character of students. In addition, integrated learning must be able to develop indicators of each subject's competency and character to be relevant to the development and needs of students. Based on this, observation of core learning activities shows that the performance of elementary school teachers is very high.

Preliminary activities carried out by respondents have high scores indicating that the teacher has prepared students psychologically and physically to begin the learning process. The teacher has also motivated contextual students regarding the benefits and application of teaching material in daily life as an important component. The introduction activity can be done by giving real examples according to the characteristics of the students. The majority of teachers systematically begin learning by asking exploratory questions related to basic knowledge. It helps teachers to brainstorm student logical thinking process, help them develop new idea about new material and prepare them to start the class (Hashempour, Rostampour, \& Behjat, 2015). Preliminary activities included in the observation indicate that the teacher explains the aspects and scope of activities according to the learning instrument. Whereas, at the core activity, the most widely used learning model by the teacher is lectures and question and answer performance of teacher performance which can be clearly observed and assessed in this activity. The closing activities carried out by the teacher include evaluating a series of activities and learning outcomes. In addition, closing activities have an important role in helping students to strengthen the material that has been received in learning activities. By following the learning instrument, teachers create a systematic teaching process and help to assess properly (Embo, Driessen, Valcke, \& van der Vleuten, 2015).

The teacher performance in this study was only measured based on the learning point of view. In addition, the data generated only described teaching performance but did not explain other factors both internally and externally. More in-depth research is needed to explore the various factors that might have a 
comprehensive and holistic effect. Not only that, teacher performance research is very important to do periodically because it is able to measure the level of achievement of the teacher's success in carrying out the task as a teacher.

Periodic assessments will be able to obtain an overview of the quality of the teacher in carrying out the main tasks, so that the results can be used as a control tool and guidance material for the principal. in addition, regular and continuous assessment of learning programs is effective for achieving competencies developed (Petrie \& Williams, 2018). An additional benefit obtained from teacher performance assessment activities is to see whether competency-based learning development has been able to develop the potential of students (Menon, 2020).

\section{CONCLUSION}

Teacher performance is a behavior or response that gives the results which have been achieved by the teacher as measured by the competency specifications that the teacher must have. Teacher performance has a very high causative effect with the activities of planning, implementing and evaluating the learning done by the teacher. However, performance has no relationship or significant relationship to the working period group and gender. Teacher performance appraisal should be done to determine the performance of educators in conducting qualified education. This study presents some implications for improving teacher performance in elementary schools including planning, implementing, and evaluating. It should be noted that this paper investigates the teacher performance in elementary schools located in Semarang City. Therefore, it is highly suggested future researchers conduct studies of teacher performance in wider areas or different countries.

\section{REFERENCES}

Alghamdi, A. K. H., \& Al-Salouli, M. S. (2013). Saudi elementary school science teachers' beliefs: Teaching science in the new millennium. International Journal of Science and Mathematics Education, 11(2), 501-525. https://doi.org/10.1007/ s10763-012-9353-0.

Awang, Z., Afthanorhan, W. M. A. W., \& Asri,
M. A. M. (2015). Parametric and non parametric approach in Structural Equation Modeling (SEM): The application of bootstrapping. Modern Applied Science, 9(9), 58-67. https://doi.org/10.5539/mas. v9n9p58.

Bakar, R. (2018). The influence of professional teachers on Padang vocational school students' achievement. Kasetsart Journal of Social Sciences, 39(1), 67-72. https:// doi.org/10.1016/j.kjss.2017.12.017.

Blömeke, S., \& Delaney, S. (2012). Assessment of teacher knowledge across countries: A review of the state of research. ZDM - International Journal on Mathematics Education, 44(3), 223-247. https://doi. org/10.1007/s11858-012-0429-7.

Dutta, R., Halder, S., \& Sen, M. K. (2017). Teacher effectiveness and related characteristics: A systematic review. The Online Journal of New Horizons in Education, 7(1), 143-162. http://www. tojned.net/journals/tojned/articles/v07i01/ v07i01-16.pdf.

Early, D. M., Maxwell, K. L., Burchinal, M., Alva, S., Bender, R. H., Bryant, D., ... \& Zill, N. (2007). Teachers' education, classroom quality, and young children's academic skills: Results from seven studies of preschool programs. Child Development, 78(2), 558-580. https://doi. org/10.1111/j.1467-8624.2007.01014.x.

Embo, M., Driessen, E., Valcke, M., \& van der Vleuten, C. P. M. (2015). Integrating learning assessment and supervision in a competency framework for clinical workplace education. Nurse Education Today, 35(2), 341-346. https://doi. org/10.1016/j.nedt.2014.11.022.

Hakim, A. (2015). Contribution of competence teacher (pedagogical, personality, professional competence and social) on the performance of learning. The International Journal of Engineering and Science (IJES), 4(2), 1-12. http:// www.theijes.com/papers/v4-i2/Version-3/ A42301012.pdf. 
Hashempour, Z., Rostampour, M., \& Behjat, F. (2015). The effect of brainstorming as a pre-writing strategy on EFL advanced learners' writing ability. Journal of Applied Linguistics and Language Research, 2(1), 86-99. http://www.jallr.com/index.php/ JALLR/article/view/23.

Hassan, B., Alias, M., Saleh, K. M., \& Awang, H. (2017). Students' perceptions of their teachers' performance in teaching engineering drawing in Nigerian tertiary institutions. Path of Science, 3(10), 30013012. https://doi.org/10.22178/pos.27-4.

Hervie, D. M., \& Winful, E. C. (2018). Enhancing teachers' performance through training and development in Ghana education service (a case study of ebenezer senior high school). Journal of Human Resource Management, 6(1), 1-8. https://doi. org/10.11648/j.jhrm.20180601.11.

Hosseinifard, S. Z., \& Abbasi, B. (2012). Evaluation of process capability indices of linear profiles. International Journal of Quality and Reliability Management, 29(2), 162-176. https://doi. org/10.1108/02656711211199892.

Keengwe, J., \& Onchwari, G. (2011). Fostering meaningful student learning through constructivist pedagogy and technology integration. International Journal of Information and Communication Technology Education, 7(4), 1-10. https:// doi.org/10.4018/jicte.2011100101.

Lee, J. C. K., Lam, W. P., \& Li, Y. Y. (2003). Teacher evaluation and effectiveness in Hong Kong: issues and challenges. Journal of Personnel Evaluation in Education, 17(1), 41-65. https://doi. org/10.1023/A:1025027029643.

Mahgoub, Y. M., \& Alyas, S. A. (2014). Development of teacher performance and its impact on enhancing on the quality of the educational process. La Pensée, 76(2), 169-179.

Markle, B. R., \& Banion, T. O. (2014). Assessing affective factors to improve retention and completion. Learning Abstracts, 17(11),
1-16. http://media.wallace.edu/wcc/O Banion/Articles\%20on\%20Student $\% 20$ Success/Assessing\%20Affective $\% 20$ Factors \%20to\%20Improve $\% 20$ Retention\%20and\%20Completion.pdf.

Menon, D. (2020). Influence of the sources of science teaching self-efficacy in preservice elementary teachers' identity development. Journal of Science Teacher Education, 31(4), 460-481. https://doi.org /10.1080/1046560X.2020.1718863.

Morgan, G. B., Hodge, K. J., Trepinski, T. M., \& Anderson, L. W. (2014). The stability of teacher performance and effectiveness: implications for policies concerning teacher evaluation. Education Policy Analysis Archives, 22(95), 1-21. https:// doi.org/10.14507/epaa.v22n95.2014.

Muin, J. A., Riyanto, R., \& Wibowo, S. B. (2020). Teacher competencies for dyslexia students. Universal Journal of Educational Research, 8(3), 904-908. https://doi. org/10.13189/ujer.2020.080322.

Mumpuniarti, M., Handoyo, R. R., Pinrupitanza, D. T., \& Barotuttaqiyah, D. (2020). Teacher's pedagogy competence and challenges in implementing inclusive learning in slow learner. Cakrawala Pendidikan, 39(1), 217-229. https://doi. org/10.21831/cp.v39i1.28807.

Murkatik, K., Harapan, E., \& Wardiah, D. (2020). The influence of training education and teacher competence on VHS teacher's performance. Journal of Social Work and Science Education, 1(1), 58-69. https:// ejournal.karinosseff.org/index.php/jswse/ article/view/10.

Obara, S., \& Sloan, M. (2010). Classroom experiences with new curriculum materials during the implementation of performance standards in mathematics: A case study of teachers coping with change. International Journal of Science and Mathematics Education, 8(2), 349372. https://doi.org/10.1007/s10763-0099176-9.

Ohle, A., Boone, W. J., \& Fischer, H. E. (2015). 
Investigating the impact of teachers' physics ck on students outcomes. International Journal of Science and Mathematics Education, 13(6), 12111233. https://doi.org/10.1007/s10763014-9547-8.

Petrie, I., \& Williams, K. (2019). Teacher appraisal. In G. Upton (Ed.). Staff training and special educational needs (vol 56). New York, NY: Routledge, pp. 127-136.

Rinantanti, Y., Bin-Tahir, S. Z., \& Aminah. (2019). The impact of EFL senior high school teachers' performance in Papua, Indonesia toward the students' English learning achievement. Asian EFL Journal, 23(3.3), 431-447.

Siri, A., Supartha, I. W. G., Sukaatmadja, I. P. G., \& Rahyuda, A. G. (2020). Does teacher competence and commitment improve teacher's professionalism. Cogent Business and Management, 7(1), 1-13. https://doi.org/10.1080/23311975.2020.1 781993.

Smits, I. A. M., Timmerman, M. E., \& Stegeman, A. (2016). Modelling non-normal data: The relationship between the skew-normal factor model and the quadratic factor model. British Journal of Mathematical and Statistical Psychology, 69(2), 105121. https://doi.org/10.1111/bmsp.12062.

Sumual, M. Z. I., \& Ali, M. (2017). Evaluation of primary school teacher's pedagogical competence in implementing curriculum. Journal of Education and Learning, 11(3), 343-350. https://doi.org/10.11591/ edulearn.v11i3.6429.

Usop, A. M., Askandar, D. K., LangguyuanKadtong, M., \& Usop, D. A. S. O. (2013). Work performance and job satisfaction among teachers. International Journal of Humanities and Social Science, 3(5), 245252. http://www.ijhssnet.com/journals/ Vol_3_No 5_March_2013/25.pdf.

Vieira, A. L. (2011). Interactive LISREL in practice: Getting started with a SIMPLIS approach. New York, NY: Springer. https:// doi.org/10.1007\%2F978-3-642-18044-6.

Voelkle, M. C., Oud, J. H. L., von Oertzen, T., \& Lindenberger, U. (2012). Maximum likelihood dynamic factor modeling for arbitrary N and T using SEM. Structural Equation Modeling, 19(3), 329-350. https://doi.org/10.1080/10705511.2012.6 $\underline{87656 .}$ 